\title{
Does Criollo cocoa have the same ecophysiological characteristics
} as Forastero?

\author{
Wilmer Tezara ${ }^{1}{ }^{1 *}$, Rosa Urich ${ }^{1}$, Ramón Jaimez ${ }^{2}$, Ilsa Coronel ${ }^{1}$, Osmary \\ Araque ${ }^{2}$, Carmen AzÓCar², Iraima Chacón ${ }^{3}$
}

Botamical Sciences 94 (3): 563-574, 2016

DOI: $10.17129 /$ botsci.552

'Instituto de Biología Experimental, Facultad de Ciencias, Universidad Central de Venezuela. Apartado 47829, Caracas 1040, Venezuela.

${ }^{2}$ Instituto de Investigaciones Agropecuarias. Laboratorio Ecofisiología de Cultivos. Facultad de Ciencias Forestales y Ambientales. Universidad de los Andes

${ }^{3}$ Corpozulia. Estación Chama. Km 42 Santa Bárbara- El Vigía. Estado Zulia.

${ }^{4}$ Facultad de Ciencias Agropecuarias y Ambientales, Universidad Técnica Luis Vargas Torres, Estación Experimental Mútiles, Esmeraldas, Ecuador. Proyecto Prometeo - Secretaría de Educación Superior, Ciencia, Tecnología e Innovación, Ecuador

*Corresponding author: wilmer.tezara@ciens.ucv.ve

\section{Abstract}

Background: The Palma Real Mountain of Venezuela has Criollo and Forastero cocoa trees of over 50 years old. These individuals are considered ancestral representatives of high quality cocoa that have survived for many years in this location without any agronomic management.

Question: This study shows some physiological traits of these old trees, in order to determine whether differences exist in photosynthetic capacity and some biochemical parameters between the two types of cocoa growing under natural conditions.

Studied species: Theobroma cacao L.

Study site and years of study: was done in the mountain Palma Real in the Island of Margarita, Edo. Nueva Esparta, in January 2008 and November 2009.

Methods: The individuals present in the area were initially characterized as Criollo or Forastero and gas exchange, chlorophyll fluorescence and the response of the photosynthetic rate (A) to intercellular $\mathrm{CO}_{2}$ concentration $\left(\mathrm{C}_{\mathrm{i}}\right)$ and photosynthetic photon flux density (PFD), carbon isotope ratio $\left(\delta^{13} \mathrm{C}\right)$, nitrogen isotope ratio $\left(\delta^{15} \mathrm{~N}\right)$, leaf $\mathrm{N}$ and chlorophyll content were evaluated.

Results: The results showed that the gas exchange characteristics of Criollo cocoa differ slightly from those of Forastero. However, similar PFD saturation $\left(\sim 400 \mu \mathrm{mol} \mathrm{m}^{-2} \mathrm{~s}^{-1}\right)$ with values of A at saturating light approaching $4 \mu \mathrm{mol} \mathrm{m}{ }^{-2} \mathrm{~s}^{-1}$, carboxylation efficiency (CE) and photochemical activity, indicated a comparable photosynthetic capacity in both cocoa types.

Conclusions: There are apparently no physiological disadvantages in Criollo compared with Forastero trees and therefore both could be recommended as suitable materials for cultivation in similar environments, thereby expanding cultivation of high quality cocoa.

Key words: A/C curves, fluorescence, photosynthetic activity, Theobroma cacao, water potential.

\section{¿Tiene el cacao Criollo las mismas características ecofisiológicas que el Forastero? Resumen}

Antecedentes: La Montaña Palma Real en Venezuela tiene árboles de cacao Criollo y Forastero de más de 50 años de edad. Estos individuos se consideran representantes ancestrales de cacao de alta calidad que han sobrevivido durante muchos años en este lugar sin ningún tipo de manejo agronómico.

Pregunta: Este estudio muestra algunas características fisiológicos de estos árboles, con el fin de determinar si existen diferencias en la capacidad fotosintética y algunos parámetros bioquímicos entre los dos tipos de cacao que crecen en condiciones naturales.

Especie estudiada: Theobroma cacao L.

Sitio de estudio y años del estudio: se hizo en la montaña Palma Real en la Isla de Margarita, Estado Nueva Esparta, en enero de 2008 y noviembre de 2009.

Métodos: Los individuos presentes en la zona, inicialmente se caracterizaron como cacao Criollo o Forastero; se evaluó el intercambio gaseoso, la fluorescencia de la clorofila, la respuesta de la tasa fotosintética (A) a la concentración intercelular de $\mathrm{CO}_{2}\left(\mathrm{C}_{\mathrm{i}}\right)$ y a la densidad de flujo de fotones (PFD), la relación de isótopos de carbono $\left(\delta^{13} \mathrm{C}\right)$, la proporción de isótopos de nitrógeno $\left(\delta^{15} \mathrm{~N}\right)$, y el contenido de clorofila y $\mathrm{N}$ foliar.

Resultados: Los resultados mostraron que las características de intercambio de gases de cacao Criollo difieren levemente de los de cacao Forastero. Sin embargo, la PFD de saturación fue similar $\left(\sim 400 \mu \mathrm{mol} \mathrm{m}^{-2} \mathrm{~s}^{-1}\right)$ con valores de A a luz saturante cerca de $4 \mu \mathrm{mol} \mathrm{m}^{-2} \mathrm{~s}^{-1}$, la eficiencia de carboxilación (CE) y la actividad fotoquímica, indicaron una capacidad fotosintética comparable en ambos tipos de cacao.

Conclusiones: Aparentemente no hay desventajas fisiológicas en el cacao Criollo en comparación con los árboles de cacao Forastero, por lo tanto ambos podrían ser recomendados como materiales adecuados para el cultivo en ambientes similares al lugar de estudio, aumentando así el cultivo de cacao de alta calidad. 
ocoa (Theobroma cacao L.) is an allogamous, woody species of the family Malvaceae (de Almeida and Valle 2007), native to the rainforests of the Amazon basin and other tropical areas of Central and South America. Despite its center of origin, of the 8.6 million hectares planted worldwide only $17 \%$ correspond to America and the Caribbean (Carr and Loockwood 2011), with a production of 4,23 million ton of cocoa in 2014-2015 (ICCO, 2015), i.e. an average production of $560 \mathrm{~kg} / \mathrm{ha}$. Its economic importance lies in being a small-scale cultivation from which depend 5-6 million farmers (de Almeida and Valle 2007; Carr and Loockwood 2011). Cocoa is a shade crop, intolerant to drought (Belsky and Siebert 2003) and its productivity is strongly affected by the distribution of rainfall and duration of drought periods (Balasimha et al. 1991; Bae et al. 2008).

There are three types or morphogenetically different groups of cocoa known as "Criollo" (native of Venezuela), "Forastero" (original from the Amazon basin) and "Trinitario" produced naturally in the island of Trinidad (a cross between Criollo and Forastero), which differ in quality of the almonds, vigor and yield (Criollo, high quality, and Forastero with different qualities and tastes; Cheesman 1944).

Forastero and Trinitario cocoa are considered of lesser quality but are widely grown worldwide because of some advantages in performance and resistance to diseases (Girón et al. 2007). Recently, Motamayor et al. (2008) suggested a new classification of cocoa germplasm grouped into 10 genetic groups, which reflects the diversity of cocoa and a better approach than the previous classification (Motamayor et al. 2002). The Criollo cocoa identified within this group has a low genetic diversity (Motamayor et al. 2002) and its quality is considered one of the best in the world (Elwers et al. 2009) although this variety is susceptible to disease. Cocoa exhibits considerable genetic variability regarding morphological and physiological traits (Daymond et al. 2002a; b). However, studies of genotypic variation of photosynthetic traits in cocoa are limited (Daymond et al. 2011).

Most ecophysiological studies have been conducted in cocoa seedlings or saplings in laboratory, greenhouses and nurseries. Low photosynthetic rates (A) and stomatal conductance $\left(\mathrm{g}_{\mathrm{s}}\right)$ have been reported in cocoa trees with reductions due to water deficit, high vapor pressure deficit (VPD) and high photosynthetic photon flux density (PFD) among other abiotic factors that could cause stress (Deng et al. 1989; de Almeida and Valle 2007; Acheampong et al. 2013; Ávila-Lovera et al. 2016). There are limited studies on ecophysiological responses to water and light availability of different genotypes of adult cocoa trees, both in agricultural ecosystems and natural habitats (Moser et al. 2010; Araque et al. 2012; Jaimez et al. 2013; Ávila-Lovera et al. 2016).

The cultivation of cocoa in Venezuela is mainly located in three regions: Southwest, Northeast, representing the major production area ( $43 \%$ of total production) and the North Central Coast (González-Jiménez 1999). Most of the plantations have some combinations of the three cocoa types creating mosaics of plants with differences in the quality and morphology of fruits. However, some plantations maintain highly homogeneous cocoa.

Although not recognized as a cocoa producing area in Venezuela, some old, abandoned plantations are found in "Cacao" and "Palma Real" mountain of Isla Margarita, Nueva Esparta state (Northeast). These agroforestry systems have combination of trees of mamey (Pouteria sapota), avocado (Persea americana), copey (Clusia rosea), breadfruit (Artocarpus communis) in the upper layer of the forest and cocoa in the lower. The first biometric and morphometric description of cocoa plants in this area, conducted by Girón et al. (2007), showed the existence of populations of high quality wild Criollo and Forastero plants (Figure 1A, B), considered representatives of the first plantations in the country. These plants must have particular physiological traits that have allowed them to grow for a long time in this habitat.

The existence of this plantation for so many years in this location seems to confirm that in regions with little access to inorganic fertilizers, litter fall can maintain soil fertility (Isaac et al. 2007). Moreover, the reduction in wind speed and evapo-transpiration by trees that provide the shade reduce the water deficit and high temperature of air and soils during the dry season (Beer et al. 1998). Although in the island of Margarita, the climate is semiarid, mountain regions with 900 m or higher, such as the "Cacao" and "Palma Real" mountains, have microclimatic conditions that enable the development of this agricultural system. These cocoa plantations allow 


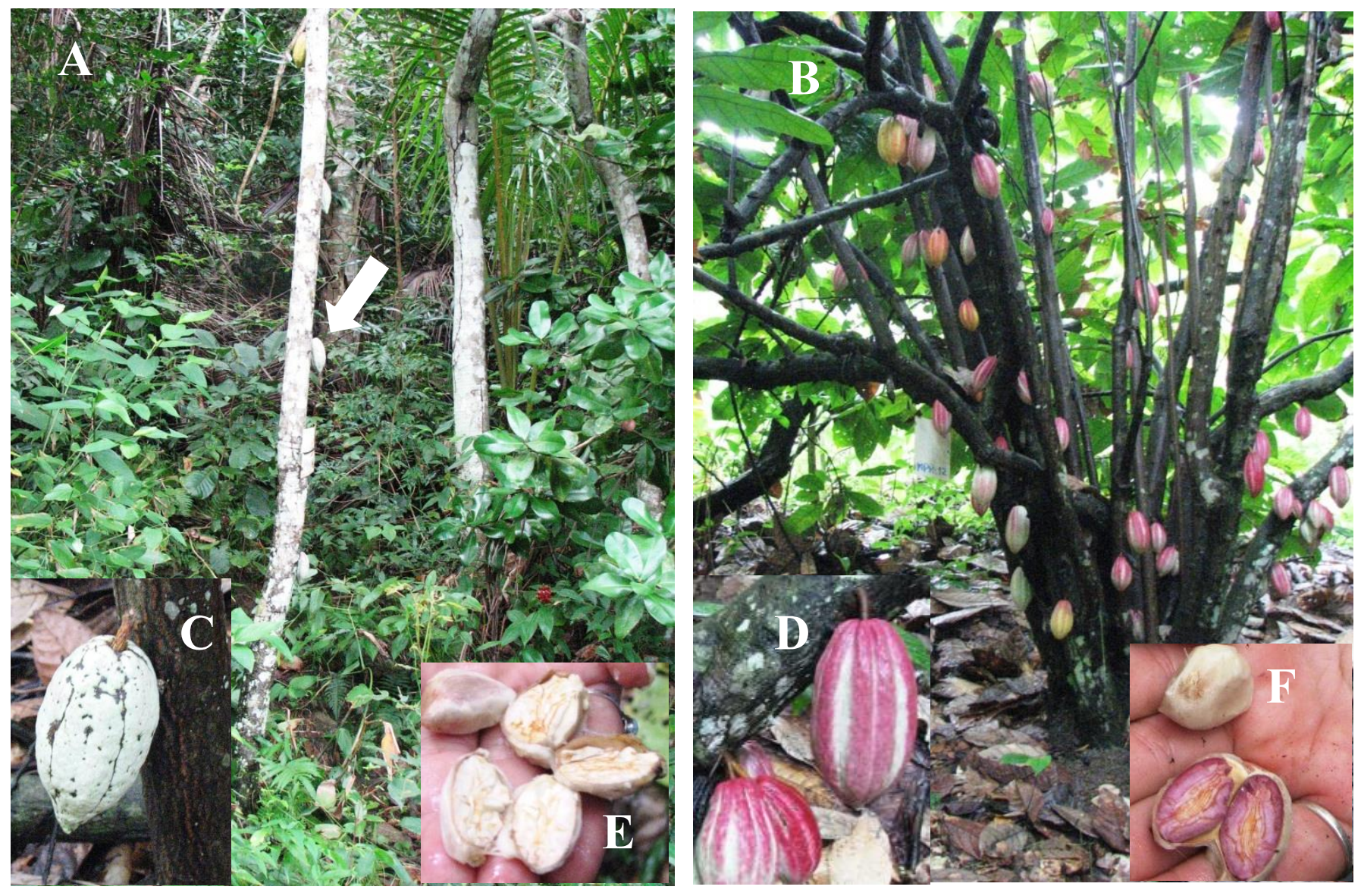

Figure 1. A) wild individuals (adults $>50$ years old) of Criollo cocoa with main stem of approximately. 8-m-high; the arrow points to a Criollo cocoa pod. B) individual of Forastero cocoa with profuse side-branching stems and large pod production; C) and D) detail of pods, E) and F) form and color of almonds of Criollo and Forastero cocoa, respectively.

the study of the physiological characteristics of old Criollo cocoa and its differences with the cultivars recently introduced and currently used in Venezuela.

While many plantations in Venezuela are mainly of Trinitario and Forastero cultivars, the strategy established in the last decade is the gradual introduction of hybrids and Criollo cultivars with high almond quality in extended regions of the country. Physiological responses of Criollo cocoa to water deficit have been reported and osmotic adjustment importance in some cultivars is highlighted (Rada et al. 2005; Araque et al. 2012). Different cultivars from major cocoa areas of the country, including the island of Margarita, grown in a germplasm bank in the central region, showed significant seasonal and between-cultivar physiological differences (Pereyra 2007; Tezara et al. 2009).

The aim of this study was to assess physiological traits such as water potential, gas exchange photochemical activity of photosystem II and biochemical parameters of old cocoa Criollo and Forastero trees that have survived without agronomic management, to ascertain if there are physiological differences between them.

\section{Materials and methods}

Study area and plant material. The measurements were performed in adult individuals in a premontane rainforest (Ewel et al. 1976) located at $11^{\circ} 01^{\prime} \mathrm{N}, 63^{\circ} 53^{\prime} \mathrm{W}$ and $470 \mathrm{~m}$ in the mountain Palma Real, in Margarita Island, Edo. Nueva Esparta, Venezuela, in January 2008 and November 2009. The rainy season occurs between November and January and the dry season between June and August. Annual rainfall is $700-800 \mathrm{~mm}$. This rainfall pattern and the occurrence of fog 
at high altitudes have allowed the establishment of tropical deciduous and transition forests with trees that can reach $40 \mathrm{~m}$ in height (Hoyos 1985).

Cocoa trees are shaded by several fruit trees randomly planted. The Criollo individuals (Figure 1A) were identified by fruit characteristics (Figure 1C), whitish cotyledons (Figure 1E), light green young leaves and pubescent leaf petioles. The Forastero cocoa (Figure 1B, 1D) had light to dark violet cotyledons (Figure 1F), dark new leaves (from red to violet) and glabrous leaf petioles. Microsatellite analysis showed that individuals corresponded to ancestral Criollo or Forastero cocoa (Marcano-de Segovia 2007).

Physiological measurements. All physiological measurements described below were made on fully expanded leaves of adult trees.

Water relations. Leaf water potential $(\Psi)$ was measured at 06:00 and 12:00 $\mathrm{h}$ in leaves of five individuals of each type of cocoa $(n=5)$ with a pressure bomb (PMS, Corvallis, Oregon, USA).

Gas exchange. Measurements of gas exchange: photosynthetic rate, A; transpiration rate, E; stomatal conductance, $\mathrm{g}_{\mathrm{s}}$; intercellular $\mathrm{CO}_{2}$ concentration, $\mathrm{C}_{\mathrm{i}}$, and water use efficiency, WUE were performed with a portable infrared gas analyzer (CIRAS 2, PP Systems, Hitchin, UK) used in conjunction with an assimilation chamber (PLC, PP Systems, Hitchin, UK), at ambient $\mathrm{CO}_{2}$ concentration $\left(\mathrm{C}_{\mathrm{a}}\right)$ of $380 \mu \mathrm{mol} \mathrm{mol}^{-1}, 21 \% \mathrm{O}_{2}$, PFD of $400 \mu \mathrm{mol} \mathrm{m}^{-2} \mathrm{~s}^{-1}$ and a leaf temperature $\left(T_{L}\right)$ of $28 \pm 0.5^{\circ} \mathrm{C}$. Gas exchange was measured between 9:00 and 11:00 h since previous measurements showed that $\mathrm{A}$ at maximum within these hours.

Curves of photosynthetic rate vs. intercellular $\mathrm{CO}_{2}$ concentration $\left(A / C_{i}\right)$. Response curves of A to intercellular $\mathrm{CO}_{2}$ concentration $\left(\mathrm{A} / \mathrm{C}_{\mathrm{i}}\right.$ curves $)$ were done in four individuals of each type of cocoa $(\mathrm{n}=4)$ by decreasing $\mathrm{C}_{\mathrm{i}}$ from approximately $298 \mu \mathrm{mol} \mathrm{mol}^{-1}$ (at which A at $\mathrm{C}_{\mathrm{a}}=380 \mu \mathrm{mol} \mathrm{mol}^{-1}$ was initially measured) to zero and then progressively increasing $\mathrm{C}_{\mathrm{i}}$ to $1,200 \mu \mathrm{mol} \mathrm{mol}{ }^{-1} \mathrm{CO}_{2}$. Measurements were made between 09:00 and11:00 h at 400 $\pm 10 \mu \mathrm{mol} \mathrm{m}^{-2} \mathrm{~s}^{-1}$ of PFD, $21 \% \mathrm{O}_{2}$ and $\mathrm{T}_{\mathrm{L}}$ of $28 \pm 0.5^{\circ} \mathrm{C}$. The $\mathrm{A} / \mathrm{C}_{\mathrm{i}}$ curves were fitted to the empirical equation $\mathrm{A}=\mathrm{b}+\mathrm{d} \times \mathrm{e}^{\mathrm{k} \times \mathrm{C}_{\mathrm{i}}}$, where $\mathrm{b}$ is $\mathrm{C}_{\mathrm{i}}$-saturated photosynthetic rate $\left(\mathrm{A}_{\mathrm{CO}_{2} \mathrm{sat}}\right.$ and $(\mathrm{b}+\mathrm{d})$ is diurnal respiration rate $\left(\mathrm{R}_{\mathrm{d}}\right)($ Tezara et al. 1998). Carboxylation efficiency (CE) was calculated from the initial slope of the curve as $\mathrm{k} \times \mathrm{d}$ and $\mathrm{CO}_{2}$ compensation point $(\Gamma)$ as $\mathrm{Ln}(-\mathrm{b} / \mathrm{d}) / \mathrm{k}$. The relative stomatal limitation $\left(\mathrm{L}_{\mathrm{s}}\right)$ was calculated as, $\mathrm{L}_{\mathrm{s}}=100 \times\left(A_{o}-A\right) / A_{0}$, where $\mathrm{A}_{\mathrm{o}}$ is $\mathrm{A}$ at $\mathrm{C}_{\mathrm{i}}=\mathrm{C}_{\mathrm{a}}$, i.e. at infinite $\mathrm{g}_{\mathrm{s}}$ (Farquhar and Sharkey 1982).

Curves of photosynthetic rate vs. photosynthetic photon flux density (A/ PFD). Response curves of A to PFD (A/PFD) were done in four individuals of each type of cocoa $(n=4)$ by decreasing PFD from $400 \mu \mathrm{mol} \mathrm{m}^{-2} \mathrm{~s}^{-1}$ (at which A was initially measured) to 0 and then progressively increasing it from to $1.500 \mu \mathrm{mol} \mathrm{m}^{-2} \mathrm{~s}^{-1}$ in eight steps, using the leaf microclimate control system of the CIRAS 2. Measurements were done between 09:00-11:00 h at 380 $\pm 10 \mu \mathrm{mol} \mathrm{mol}^{-1}$ of C$_{\mathrm{a}}$, $21 \% \mathrm{O}_{2}$ and $\mathrm{T}_{\mathrm{L}}$ of $28 \pm 0.5^{\circ} \mathrm{C}$.

Photochemical activity of PSII. Chlorophyll a fluorescence was measured on attached dark-acclimated leaves $(\mathrm{n}=6)$ with a PAM 2100 fluorometer (Walz, Effeltrich, Germany) using the protocol described by Genty et al. (1989). Maximum quantum yield of PSII $\left(\mathrm{F}_{\mathrm{v}} / \mathrm{F}_{\mathrm{m}}\right)$ was measured in situ at predawn in dark-adapted leaves. Photochemistry activity response curves to PFD were done in four individuals $(\mathrm{n}=4)$ in each cultivar. Relative quantum yield of PSII $\left(\Phi_{\mathrm{PSII}}\right)$ at steady state A was calculated as, $\Phi_{\mathrm{PSII}}=F_{m}{ }_{m}-F_{s} / F^{\prime}{ }_{m}$, where $\mathrm{F}_{\mathrm{s}}$ and $\mathrm{F}_{\mathrm{m}}{ }_{\mathrm{m}}$ are steady state and maximum fluorescence in light, respectively. Photochemical $\left(\mathrm{q}_{\mathrm{P}}\right)$ and non-photochemical $\left(\mathrm{q}_{\mathrm{N}}\right)$ quenching coefficients were calculated from measurements of fluorescence. Electron transport rate of PSII (J) was estimated as $J=\Phi P S I I \times P F D \times a \times 0.5$, where $a$ is the fraction of incident PFD absorbed by the leaf (0.84).

Chlorophyll content and isotope ratios of carbon and nitrogen $\left(\delta^{13} C, \delta^{15} N\right)$. Chlorophyll extraction was performed on an aliquot of fresh leaf samples $(\mathrm{n}=5)$ of known area, using $80 \%$ acetone cold (Bruinsma 1963). For each type of cocoa, leaf samples of four individuals $(n=4)$ were ground and then analyzed for carbon isotope ratio $\left(\delta^{13} \mathrm{C}\right)$, nitrogen isotope ratio $\left(\delta^{15} \mathrm{~N}\right)$ and leaf $\mathrm{N}$ content at the University of Illinois-Chicago, using an elemental analyzer (Costech, Valencia, California) coupled to a Delta+XL isotope ratio mass spectrometer (Finnigan, Bremen, Germany) operated in continuous flow and run against NIST and lab standards to a precision of $0.05 \%$ for $\mathrm{C}$ and $0.15 \%$ for $\mathrm{N}$.

Specific leaf area $(S L A)$. Specific leaf area was measured in discs $(\mathrm{n}=10)$ of the same leaves 
used for measurements of gas exchange. The discs were dried to constant weight at $70{ }^{\circ} \mathrm{C}$ and SLA determined as area of leaf discs/ dry mass.

Statistical Analysis. Results are presented as the mean of each variables measurements made in 2008 and $2009 \pm$ standard error. The Statistica 5.5 statistical package was used for analysis of variance (ANOVA, with a significance level of $p<0.05$ ) and Tukey test was used as post hoc test. The graphics were done using Sigmaplot 11.0.

\section{Results}

Water status, instantaneous gas exchange and photochemical activity. No significant differences were found in $\Psi$ at dawn and noon between the two types of cocoa (Table 1). Criollo cocoa showed higher instantaneous values of A (34\%), $\mathrm{g}_{\mathrm{s}}$ (16\%), E (14\%) and WUE (15\%) than Forastero, while in both types of cocoa $C_{i}$ was similar (Table 1). The maximum quantum yield $\left(\mathrm{F}_{\mathrm{v}} / \mathrm{F}_{\mathrm{m}}\right)$ of dark-adapted leaves and the electron transport rate $(\mathrm{J})$ measured at $400 \mu \mathrm{mol} \mathrm{m} \mathrm{m}^{-2} \mathrm{~s}^{-1}$

Table 1. Pre-dawn and midday leaf water potential $(\Psi)$. Average photosynthetic rate $(A)$, stomatal conductance $\left(\mathrm{g}_{\mathrm{s}}\right)$, transpiration $(\mathrm{E})$, intercellular $\mathrm{CO}_{2}$ concentration $\left(\mathrm{C}_{\mathrm{i}}\right)$, instantaneous water use efficiency $(\mathrm{WUE})$, maximum quantum efficiency $\left(F_{V} / F_{m}\right)$, relative quantum yield of photosystem II $\left(\Phi_{P S I I}\right)$ and electron transport rate $(J)$ of Forastero and Criollo cocoa in the "Palma Real" Mountain, Margarita Island. The results are presented as means $\pm(\mathrm{SE})$. Different letters between columns indicate significant differences for each variable $(p<0.05)$.

\begin{tabular}{lcc} 
& Forastero & Criollo \\
\hline Water Potential & & \\
$\Psi(\mathrm{MPa}) 6: 00 \mathrm{am}$ & $-0.24 \pm 0.04 \mathrm{a}$ & $-0.28 \pm 0.03 \mathrm{a}$ \\
$\Psi(\mathrm{MPa}) 12: 00 \mathrm{~m}$ & $-0.50 \pm 0.20 \mathrm{a}$ & $-0.55 \pm 0.05 \mathrm{a}$ \\
\hline Instantaneous gas exchange & & \\
$\mathrm{A}\left(\mu \mathrm{mol} \mathrm{m} \mathrm{s}^{-1}\right)$ & $3.5 \pm 0.1 \mathrm{a}$ & $4.7 \pm 0.3 \mathrm{~b}$ \\
$\mathrm{~g}_{\mathrm{s}}\left(\mathrm{mmol} \mathrm{m}^{-2} \mathrm{~s}^{-1}\right)$ & $157 \pm 10 \mathrm{a}$ & $182 \pm 7 \mathrm{~b}$ \\
$\mathrm{E}\left(\mathrm{mmol} \mathrm{m}^{-2} \mathrm{~s}^{-1}\right)$ & $1.4 \pm 0.08 \mathrm{a}$ & $1.6 \pm 0.05 \mathrm{~b}$ \\
$\mathrm{C}_{\mathrm{i}}\left(\mu \mathrm{mol} \mathrm{mol}{ }^{-1}\right)$ & $315 \pm 3 \mathrm{a}$ & $311 \pm 3 \mathrm{a}$ \\
$\mathrm{WUE}\left(\mathrm{mmol} \mathrm{CO}_{2} \mathrm{~mol}^{-1} \mathrm{H}_{2} \mathrm{O}\right)$ & $2.6 \pm 0.1 \mathrm{a}$ & $3.0 \pm 0.2 \mathrm{~b}$ \\
\hline Chlorophyll fluorescence of chl a & & \\
$\mathrm{F}_{\sqrt{ } / \mathrm{F}_{\mathrm{m}}}$ & $0.79 \pm 0.003 \mathrm{a}$ & $0.80 \pm 0.05 \mathrm{a}$ \\
$\Phi_{\mathrm{PSII}}$ & $0.32 \pm 0.03 \mathrm{a}$ & $0.40 \pm 0.04 \mathrm{~b}$ \\
$\mathrm{~J}\left(\mu \mathrm{mol} \mathrm{e} \mathrm{m}^{-2} \mathrm{~s}^{-1}\right)$ & $60 \pm 7 \mathrm{a}$ & $73 \pm 11 \mathrm{a}$ \\
\hline
\end{tabular}

Table 2. Parameters of the photosynthetic response of to intercellular $\mathrm{CO}_{2}$ concentration $\left(A / C_{i}\right), \mathrm{CO}_{2}$-saturated photosynthetic rate $\left(\mathrm{A}_{\mathrm{CO}_{2} \text { sat }}\right)$, carboxylation efficiency $(\mathrm{CE}), \mathrm{CO}_{2}$ compensation point $(\Gamma)$ and relative stomatal limitation $\left(\mathrm{L}_{\mathrm{s}}\right)$. Light curves (A/ PFD): rate of photosynthesis light-saturated $\left(\mathrm{A}_{\mathrm{PFD}}\right.$ sat), apparent quantum yield of $\mathrm{CO}_{2}$ fixation $\left(\Phi_{\mathrm{CO}_{2}}\right)$, light compensation point $(\mathrm{LCP})$ and dark respiration $\left(\mathrm{R}_{\mathrm{d}}\right)$ in leaves intact of Forastero and Criollo cocoa trees. The results are presented as means $\pm(\mathrm{SE})$. Different letters indicate significant differences for each parameter $(p<0.05)$ between columns.

\begin{tabular}{|c|c|c|}
\hline Parameters & Forastero & Criollo \\
\hline \multicolumn{3}{|l|}{ A vs $\mathrm{C}_{\mathrm{i}}$} \\
\hline $\mathrm{A}_{\mathrm{CO}_{2} \text { sat }}\left(\mu \mathrm{mol} \mathrm{m}^{-2} \mathrm{~s}^{-1}\right)$ & $10.6 \pm 0.99 a$ & $8.6 \pm 1.7 \mathrm{a}$ \\
\hline $\mathrm{CE}\left(\mathrm{mol} \mathrm{m} \mathrm{m}^{-2} \mathrm{~s}^{-1}\right)$ & $0.041 \pm 0.009 \mathrm{a}$ & $0.057 \pm 0.01 \mathrm{a}$ \\
\hline$\Gamma\left(\mu \mathrm{mol} \mathrm{mol}{ }^{-1}\right)$ & $117 \pm 9 \mathrm{a}$ & $124 \pm 6 \mathrm{a}$ \\
\hline $\mathrm{L}_{\mathrm{s}}$ & $48.7 \pm 4 \mathrm{a}$ & $43.9 \pm 4.08 \mathrm{a}$ \\
\hline \multicolumn{3}{|l|}{ A vs PFD } \\
\hline $\mathrm{A}_{\mathrm{PFD}}$ sat $\left(\mu \mathrm{mol} \mathrm{m} \mathrm{m}^{-2} \mathrm{~s}^{-1}\right)$ & $2.88 \pm 0.7 \mathrm{a}$ & $2.24 \pm 0,3 \mathrm{a}$ \\
\hline$\Phi_{\mathrm{CO}^{2}}\left(\mu \mathrm{mol} \mathrm{CO}{ }_{2} \mu \mathrm{mol}\right.$ foton $\left.{ }^{-1}\right)$ & $0.062 \pm 0.03 b$ & $0.010 \pm 0.008 \mathrm{a}$ \\
\hline $\mathrm{LCP}\left(\mu \mathrm{mol} \mathrm{m} \mathrm{m}^{-2} \mathrm{~s}^{-1}\right)$ & $55 \pm 14 \mathrm{a}$ & $57 \pm 2 \mathrm{a}$ \\
\hline $\mathrm{R}_{\mathrm{d}}\left(\mu \mathrm{mol} \mathrm{m} \mathrm{m}^{-2} \mathrm{~s}^{-1}\right)$ & $-1.51 \pm 0,8 \mathrm{a}$ & $-0.58 \pm 0.4 b$ \\
\hline
\end{tabular}


Figure 2. Curves of photosynthesis (A) vs intercellular $\quad \mathrm{CO}_{2}$ concentration $\left(\mathrm{C}_{\mathrm{i}}\right)$ of intact leaves of cocoa trees: Forastero $(\bigcirc)$ and Crio1 lo (○). Each value represents the mean $\pm S E, n=4$.

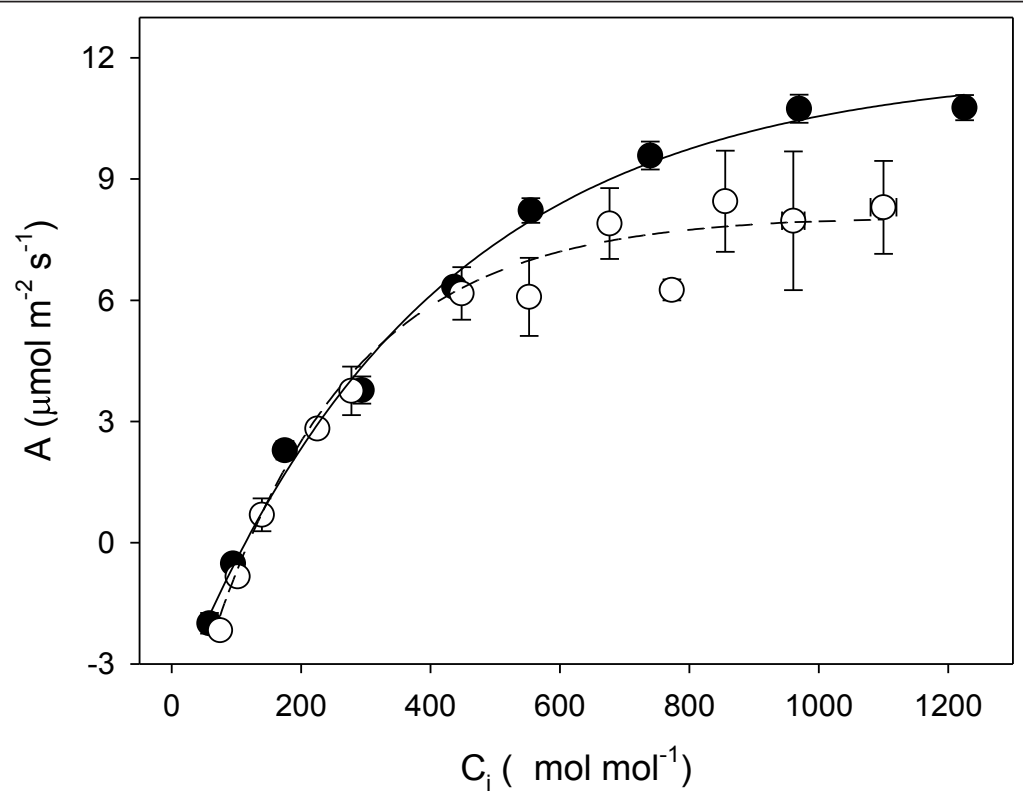

Figure 3. Curves of photosynthesis (A) vs photosynthetic photon flux density (PFD) of intact leaves of cocoa trees: Forastero cocoa tree $(\bigcirc)$ and Criollo $(\bigcirc)$.Each value represents the mean \pm $\mathrm{SE}, \mathrm{n}=4$.

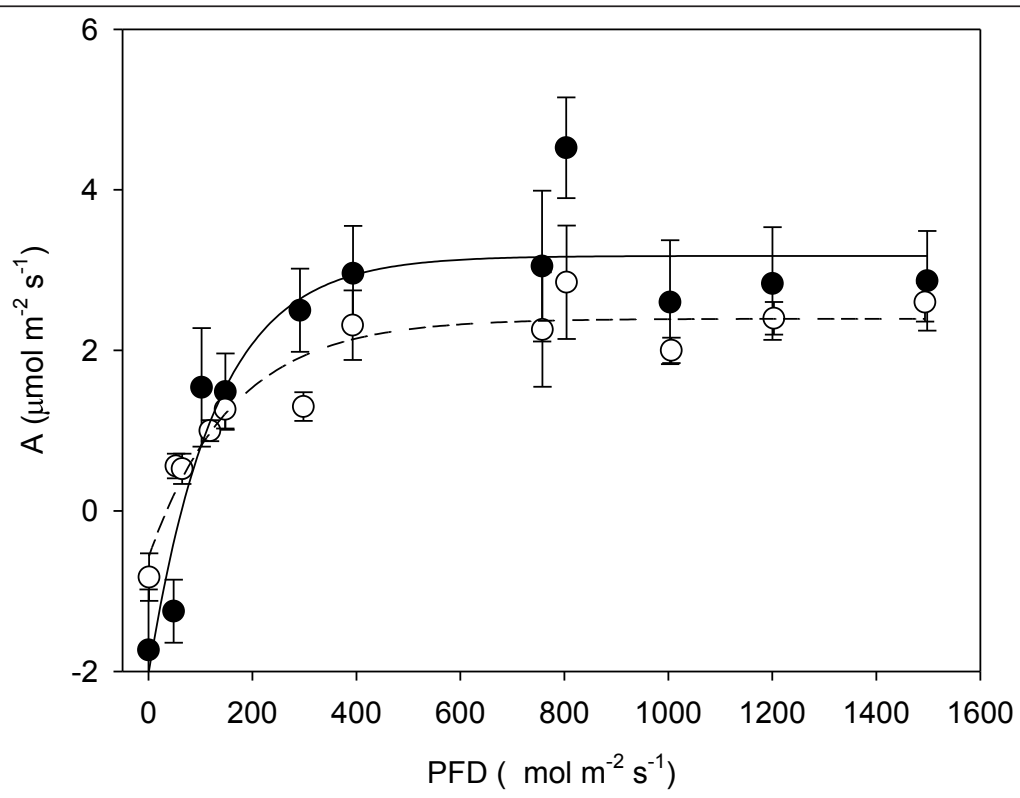

PFD was similar for the two types of cocoa, while the quantum yield of PSII $\left(\Phi_{\text {PSII }}\right)$ was slightly higher in the Criollo cocoa (Table 1).

Curves of Photosynthesis vs. intercellular $\mathrm{CO}_{2}$ concentration $\left(A / C_{i}\right)$. The $\mathrm{A} / \mathrm{C}_{\mathrm{i}}$ curves indicated no significant difference in $\mathrm{A}$ at saturating $\left[\mathrm{CO}_{2}\right]\left(\mathrm{A}_{\mathrm{CO}_{2} \text { sat }}\right)$, carboxylation efficiency $(\mathrm{CE})$ and

Table 3. Total chlorophyll content $\left(\mathrm{Chl}\right.$ ), leaf nitrogen content $(\mathrm{N})$, nitrogen $\left(\delta^{15} \mathrm{~N}\right)$ and carbon $\left(\delta^{13} \mathrm{C}\right)$ isotopic composition and specific leaf area (SLA) of Forastero and Criollo cocoa trees. The results are presented as means $\pm(\mathrm{SE})$. Different letters indicate significant differences for each parameter $(p<0.05)$ between columns.

\begin{tabular}{lcc} 
Biochemical parameters & Forastero & Criollo \\
\hline $\mathrm{Chl}{ }_{(\mathrm{a}+\mathrm{b})}\left(\mu \mathrm{cm}^{-2}\right)$ & $28.1 \pm 2.8 \mathrm{a}$ & $33.1 \pm 5.4 \mathrm{a}$ \\
$\mathrm{N}\left(\mathrm{mg} \mathrm{g}^{-1}\right)$ & $20.5 \pm 0.7 \mathrm{a}$ & $24.6 \pm 1.0 \mathrm{~b}$ \\
$\delta^{15} \mathrm{~N}(\% \mathrm{o})$ & $3.84 \pm 0.48 \mathrm{a}$ & $5.51 \pm 0.19 \mathrm{~b}$ \\
$\delta^{13} \mathrm{C}(\%)$ & $-29.21 \pm 0.2 \mathrm{a}$ & $-29.21 \pm 0.3 \mathrm{a}$ \\
$\mathrm{SLA}\left(\mathrm{cm}^{2} \mathrm{~g}^{-1}\right)$ & $172.8 \pm 3 \mathrm{~b}$ & $141 \pm 7 \mathrm{a}$ \\
\hline
\end{tabular}


Figure 4. Fluorescence parameters $v s$ the photon flux density: A) electron transport rate $(\mathrm{J})$. B) quantum yield of $\operatorname{PSII}\left(\Phi_{\text {PSII }}\right)$. C) photochemical quenching coefficient $\left(\mathrm{q}_{\mathrm{p}}\right)$ and D) non-photochemical quenching coefficient $\left(\mathrm{q}_{\mathrm{N}}\right)$ in cocoa leaves Forastero $(\bullet)$ and Criollo $(\bigcirc)$.

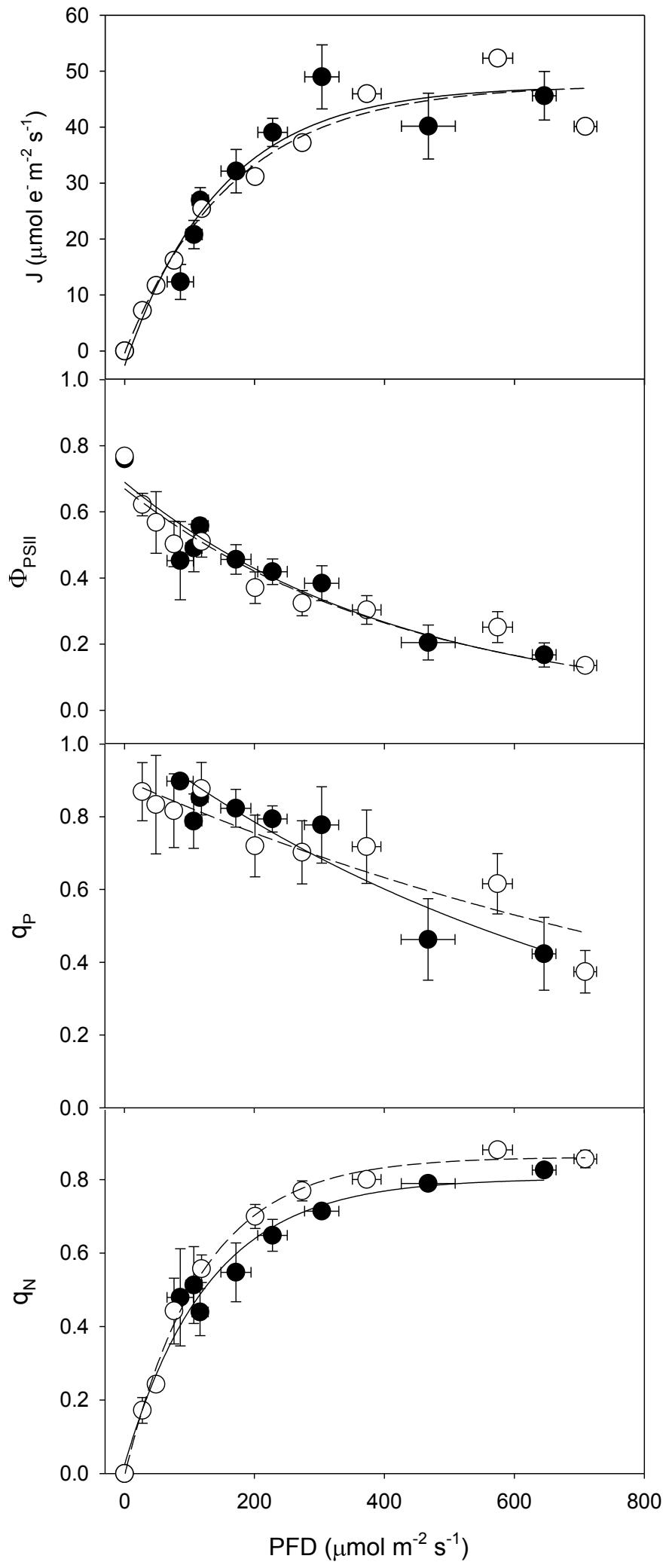

$\mathrm{CO}_{2}$ compensation point $(\Gamma)$ between the two types of cocoa (Figure 2, Table 2). The relative stomatal limitation $\left(\mathrm{L}_{\mathrm{s}}\right.$ ) averaged $46 \%$ (Table 2).

Curves of Photosynthesis vs. photosynthetic photon flux density (A/ PFD). Light curves indicated characteristics of shade plants for both types of cocoa, i.e. low rates of photosynthesis at 
saturating light ( $\left.\mathrm{A}_{\mathrm{PFD}} \mathrm{sat}\right)$, low light compensation point (LCP) and dark respiration $\left(\mathrm{R}_{\mathrm{d}}\right)$ (Table 2). The $A$ was saturated at PFD of $400 \mu \mathrm{mol} \mathrm{m}^{-2} \mathrm{~s}^{-1}$ (Figure 3). The photosynthetic rate at saturating light was similar in both types of cocoa $\left(\mathrm{A}_{\mathrm{PFD}} \mathrm{sat}\right)$. Both the apparent quantum yield of $\mathrm{CO}_{2}$ fixation $\left(\Phi_{\mathrm{CO} 2}\right)$ and $\mathrm{R}_{\mathrm{d}}$ were significant lower in the Criollo cocoa (Figure 3, Table 2).

Response curves of photochemical variables to photosynthetic photon flux density. The fluorescence parameters of the two types of cocoa showed a similar response to PFD (Figure 4A, B, C, D). Maximum J was low (about $50 \mu \mathrm{mol} \mathrm{e} \mathrm{e}^{-2} \mathrm{~s}^{-1}$ ), decreases in $\Phi_{\mathrm{PSII}}$ and $\mathrm{q}_{\mathrm{P}}$ with the increase of the PFD (Figure 4B, C) were observed, while the amount of energy dissipated as heat $\left(\mathrm{q}_{\mathrm{N}}\right)$ increased, with values greater than 0.8 when PFD was $400 \mu \mathrm{mol} \mathrm{m}^{-2} \mathrm{~s}^{-1}$ (Figure 4D).

Chlorophyll content, isotope ratios of carbon and nitrogen and specific leaf area. No differences were found in the total $\mathrm{Chl}$ content or $\delta^{13} \mathrm{C}$ between the two types of cocoa, while a higher content of foliar $\mathrm{N}$ and $\delta^{15} \mathrm{~N}$ were observed in the Criollo cocoa. Forastero showed a higher SLA compared with Criollo (Table 3).

\section{Discussion}

This work reports a physiological comparison between Forastero and Criollo old cocoa growing wild without agricultural management, pruning or fertilization. Under these conditions it is possible to evaluate the performance of cocoa plants introduced over more than 50 years ago. The physiological information presented here can be used to contribute to the knowledge needed to recommend cocoa farmers in the management and the re-establishment of good quality materials. Morphological and production differences between Criollo and Forastero cocoa are well known (Girón et al. 2007). However, physiological features that help differentiate between both types of cocoa had not until now been well evaluated.

Water status. High values of $\Psi$ early in the morning were in agreement to those reported for young plants in well-watered conditions in an agroforestry system (Jaimez et al. 2008; Tezara et al. 2009; Araque et al. 2012) and in young trees in a germplasm bank (Pereyra 2007; Ávila-Lovera et al. 2016). By the time of the study (November and January) when monthly rainfall average was high, $\Psi$ at noon of these trees indicated a low transpiration rate which may well be the result of an environment of low evaporative demand. In agroforestry systems, a reduction in wind speed and evapotranspiration contributes to lower water vapor gradients between the leaf and the atmosphere (Beer et al. 1998).

Instantaneous gas exchange. The very low average A observed for both cultivars might be associated with low $\mathrm{g}_{\mathrm{s}}$. Similarly, A values have been found to range from 0.7 to $6.5 \mu \mathrm{mol} \mathrm{m}^{-2} \mathrm{~s}^{-1}$ with low $\mathrm{g}_{\mathrm{s}}$ (20-150 $\mathrm{mmol} \mathrm{m}^{-2} \mathrm{~s}^{-1}$ ) in different studies (Joly and Hahn 1989; Daymond et al. 2011; Araque et al. 2012; de Almeida et al. 2014; Ávila-Lovera et al. 2016). Higher instantaneous A and lower E determine a significant higher WUE in Criollo compared to Forastero, suggesting that Criollo cocoa could grow well in regions with limited water availability. Values of A in Criollo and Forastero adult trees was similar to those in young cocoa trees (Pereyra 2007; Tezara et al. 2009; Ávila-Lovera et al. 2016) even with high values of $g_{s}$.

The $g_{s}$ in both types of cocoa was low (50-200 mmol m $\left.\mathrm{ms}^{-2} \mathrm{~s}^{-1}\right)$, which suggests that A may be limited by low stomatal opening. This fact was evidenced by the high values of $\mathrm{L}_{\mathrm{s}}$ (the relative limitation of A due $\mathrm{a}_{\mathrm{s}}$, approximately $46 \%$ ), indicating that photosynthesis was reduced by approximately half with respect to the photosynthetic rate at infinite $g_{s}$. These old cocoa trees showed values of $\mathrm{L}_{\mathrm{s}}$ twice the reported in young cocoa by Ávila-Lovera et al. (2016), suggesting a greater stomatal control of the photosynthetic process.

The WUE shown by the two types of cocoa were similar to those reported for younger individuals of six cultivars from Margarita Island and eastern Venezuela grown in a germplasm bank (Pereyra 2007; Tezara et al. 2009) but higher than other four cultivars of Criollo cocoa in a agroforestry system (Araque et al. 2012). The long-term WUE estimated by $\delta^{13} \mathrm{C}$ in adult trees $(-29.2 \%$ ) was similar to those found in Criollo cultivars (Ávila-Lovera et al. 2016) and significantly higher to that reported for younger cocoa trees (-30\%o) (Pereyra 2007; Tezara et al. 2009), indicating that adult trees could even present a better physiological performance during the rainy season.

$A / C_{i}$ curves. The $\mathrm{A} / \mathrm{C}_{\mathrm{i}}$ curves showed no differences in $\mathrm{A}_{\mathrm{CO}_{2} \text { sat }}$ and $\mathrm{CE}$ between both types of 
cocoa, suggesting that the Criollo and Forastero cocoa studied have similar Rubisco content and/or activity and rate of RuBP regeneration. Similar results have been reported in Criollo cocoa (Ávila-Lovera et al. 2016). Baligar et al. (2008) reported a value of $\mathrm{A}_{\mathrm{CO}_{2} \text { sat }}$ of $4 \mu \mathrm{mol} \mathrm{m} \mathrm{m}^{-2} \mathrm{~s}^{-1}$, approximately half the value found in this study.

Light curves and PSII activity. The parameters of A/PFD curves of the Criollo and Forastero cultivars indicated adaptation to shade, i.e. low $\mathrm{A}_{\mathrm{PFD}}$ sat, low $\mathrm{R}_{\mathrm{d}}$ and $\mathrm{LCP}$, without differences in these parameters between types of cocoa. Values of $\mathrm{A}_{\mathrm{PFD}} \mathrm{sat}, \Phi_{\mathrm{CO} 2}$ and $\mathrm{R}_{\mathrm{d}}$ were similar to those reported for several cocoa genotypes under different conditions (de Almeida and Valle 2007; Baligar et al. 2008; Daymond et al. 2011; Bertolde et al. 2012; de Almeida et al. 2014; ÁvilaLovera et al. 2016). The saturating PFD in both types of cocoa is relatively low, around $400 \mu \mathrm{mol} \mathrm{m}$ ${ }^{2} \mathrm{~s}^{-1}$, similar to previously reported data $\left(300-600 \mu \mathrm{mol} \mathrm{m}{ }^{-2} \mathrm{~s}^{-1}\right.$, Joly and Hahn 1989 ; Balasimha et al. 1991; Almeida et al. 2014).

Apparent quantum yield $\left(\Phi_{\mathrm{CO} 2}\right)$ of Criollo cocoa was lower $\left(0.010 \mu \mathrm{mol}\left(\mathrm{CO}_{2}\right) \mu \mathrm{mol}\right.$ (photon $)^{-1}$ ) than Forastero and from other species of Theobroma (de Almeida et al. 2014) indicating a lower light use efficiency. This can probably be a characteristic of Criollo cocoa suggesting greater sensitivity to light and the importance of cultivating this type of cacao under shade conditions. Although cocoa can tolerate high PFD, productivity and sustainability of farming and control of other biotic stresses is more efficient at lower PFD (Tscharntke et al. 2011).

There were no differences in $\mathrm{F}_{\mathrm{v}} / \mathrm{F}_{\mathrm{m}}$ (values were around 0.80) between cocoa types, without showing signs of photoinhibition indicating that the potential capacity of photosystem II is similar in Criollo and Forastero cocoa, Criollo cocoa had higher $\Phi_{\text {PSII }}$ than Forastero. The electron transport (J), equivalent to a value of A of 5-6 $\mu \mathrm{mol} \mathrm{m}^{-2} \mathrm{~s}^{-1}$, could partially explain the low rate of photosynthesis in cocoa, as was recently reported by Ávila-Lovera et al. (2016). A low rate of electron transport may cause a low rate of carboxylation due to a low synthesis of RuBP because of underproduction of photochemical compounds such as ATP and NADPH.

The response of fluorescence variables $\left(J, \Phi_{\text {PSII }}, q_{P}\right.$ and $q_{N}$ ) to PFD was similar in both types of cocoa indicating a similar photochemical capacity of PSII, which is consistent with the similarity in total chlorophyll content. Values of $\mathrm{J}, \Phi_{\mathrm{PSII}}, \mathrm{q}_{\mathrm{P}}$ and $\mathrm{q}_{\mathrm{N}}$ were similar to those reported in younger Criollo cocoa trees (Araque et al. 2012; Avila-Lovera et al. 2016). Chlorophyll content was lower than that reported for eight genotypes of cocoa (Daymond et al. 2011).

Leaf $N$ concentration and Specific leaf area. Foliar $\mathrm{N}$ values were higher than those reported for 8-year-old trees from agroforestry systems in Ghana (Isaac et al. 2007) without pre-fertilization during rainy periods. These contents were similar to those obtained by Araque et al. (2012) in fertilized three-year-old Criollo cocoa plants and five-year-old Criollo plants grown in a germplasm bank (Ávila-Lovera et al. 2016). It would be important to measure leaf $\mathrm{N}$ content during drought because decreases in leaf $\mathrm{N}$ concentration have been reported for Criollo cocoa (Araque et al. 2012; Ávila-Lovera et al. 2016). Foliar N expressed by weight was higher in the Criollo cocoa, which may confer a better nitrogen use as revealed by the higher A in this type of cocoa. The higher value of $\delta^{15} \mathrm{~N}$ Criollo cocoa also suggests a higher content of soluble nitrogen available for photosynthesis (Evans 2001).

Forastero had the highest values of SLA, which is the result of a lower content of mechanical tissue, such as cellulose and lignin (Niinemets and Kull 1998). These values are similar to those reported in Margarita Island cocoa from a germplasm bank in the Central region of Venezuela (Pereyra 2007) and lower than reported for saplings grown in greenhouse conditions (Daymond et al. 2011).

Ecophysiological similarities and differences between the two types of cocoa. The increased water use efficiency of Criollo cacao, due to higher A and E compared to Forastero could make this variety suitable for cultivation in regions with periods of restricted water supply. Additionally, the $\delta^{13} \mathrm{C}$ was higher than their counterpart young trees in a germplasm bank from Central Venezuela, indicating a greater integrated WUE. Photosynthetic response to $\mathrm{C}_{\mathrm{i}}$ and PFD and photosystem II activity of both types of cocoa was similar; in contrast, the differences in $\Phi_{\mathrm{CO} 2}$, leaf $\mathrm{N}$ content, SLA and instantaneous gas exchange indicate that Theobroma cacao exhibits physiological plasticity. This agrees with results of $\mathrm{A}, \mathrm{g}_{\mathrm{s}}$, and $\mathrm{N}$ by Daymond et al. (2011) in eight cocoa genotypes. 


\section{Conclusions}

Trees of Criollo and Forastero cultivars over 50 years of age had a photosynthetic rate similar to their younger counterparts. The prevalence of these trees for many years in this environment, with annual intervals with low rainfall, indicates that these cultivars can grow successfully in geographic areas with seasonal drought. Furthermore, the results show that the best quality Criollo cocoa is not physiologically at a disadvantage with the Forastero, at least from the perspective of their photosynthetic performance.

\section{Acknowledgments}

This study was financed by CDCH PG 03-00-6874-2007, PG 03-7981-2011, FONACIT PEI $\mathrm{N}^{\circ} 2012000649$ and Ministry of Science and Technology (MCT) project No. 200500898. Also thanks to the one anonymous reviewer for their suggestions, which improved the final version of this manuscript and Ana Herrera for critically reading the manuscript. The collaboration of Mr. Ali Guerra in the field is highly appreciated. The autors thanks especially the Proyecto Prometeo de la Secretaría de Educación Superior, Ciencia, Tecnología e Innovación de la República del Ecuador for partially sponsoring this work.

\section{Literature cited}

Acheampong K., Hadley P. and Daymond A.J. 2013. Photosynthetic activity and early growth of four cacao genotypes as influenced by different shade regimes under West African dry and wet season conditions. Experimental Agriculture 49:31-42.

de Almeida A.-A.F. and Valle R.R. 2007. Ecophysiology of the cacao tree. Brazilian Journal of Plant Physiology 19:425-448.

de Almeida A.-A.F., Gomes F.P., Araujo R.P., Santos R.C. and Valle R.R. 2014. Leaf gas exchange in species of the Theobroma genus. Photosynthetica 52:16-21

Araque O., Jaimez R.E., Tezara W., Coronel I., Urich R. and Espinoza W. 2012. Comparative photosynthesis, water relations, growth and survival rates in juvenile Criollo cacao cultivars (Theobroma cacao) during dry and wet seasons. Experimental agriculture 48:513-522.

Ávila-Lovera E., Coronel I., Jaimez R., Urich R., Pereyra G., Araque O., Chacón I. and Tezara W. 2016. Ecophysiological traits of adult trees of Criollo cocoa cultivars (Theobroma cacao L.) from a germplasm bank in Venezuela. Experimental Agriculture 52: 137-153.

Bae H., Kim S-H., Kim M.S., Sicher, R.C., Lary D., Strem M.D., Natarajan S. and Bailey B.A. 2008. The drought response of Theobroma cacao (cacao) and the regulation of genes involved in polyamine biosynthesis by drought and other stresses. Plant Physiology and Biochemistry 46:174-188.

Balasimha D., Daniel E.V. and Bhat P.G. 1991. Influence of environmental factors on photosynthesis in cocoa trees. Agriculture and Forest Meteorology 55:15-21.

Baligar V.C., Bunce J.A, Machado R.C.R. and Elson M.K. 2008. Photosynthetic photon flux density, carbon dioxide concentration and vapor pressure deficit effects on photosynthesis in cacao seedlings. Photosynthetica 46:216-221.

Beer J.M., Muschler R., Kass D. and Somarriba, E. 1998. Shade management in coffee and cacao plantations. Agroforestry Systems 38:139-164.

Belsky J.M and Siebert S.F. 2003. Cultivating cacao: implications of sun-grown cacao on local food security and environmental sustainability. Agriculture and Human Values 20:277-285.

Bertolde F.Z., Almeida A.-A.F., Pirovani C.P., Gomes F.P., Ahnert D., Baligar V.C. and Valle R.R. 2012. Physiological and biochemical responses of Theobroma cacao L. genotypes to flooding. Photosynthetica 50:447-457.

Bruinsma J. 1963. The quantitative analysis of chlorophylls a and b in plants extracts. Photochemistry Photobiology 2:241-249.

Carr M.K.V. and Lockwood G. 2011. The water relations and irrigations requirements of cacao (Theobroma cacao L.): a review. Experimental Agriculture 47:653-676

Cheesman E.E. 1944. Notes on the nomenclature, classification and possible relationships of cocoa populations. Tropical Agriculture 21:144-159.

Daymond A.J., Hadley P., Machado R.C.R. and Ng E. 2002a. Canopy characteristics of contrasting clones of cacao (Theobroma cacao). Experimental Agriculture 38:359-367.

Daymond A., Hadley P., Machado R.C.R. and Ng E. 2002b. Genetic variability in partitioning to the yield component of cacao (Theobroma cacao L.). HortScience 37:799-801. 
Daymond A.J., Tricker P.J. and Hadley P. 2011. Genotypic variation in photosynthesis in cacao is correlated with stomatal conductance and leaf nitrogen. Biologia Plantarum 55:99-104.

Deng X., Joly R.J. and Hahn D.T. 1989. Effects of plant water deficit on the daily carbon balance of leaves of cacao seedlings. Physiologia Plantarum 77:407-412.

Elwers S., Zambrano A., Rohsius C. and Lieberei R. 2009. Differences between the content of phenolic compounds in Criollo, Forastero and Trinitario cocoa seed (Theobroma cacao L.). European food Research Technology 229:937-948.

Evans R.D. 2001. Physiological mechanisms influencing plant nitrogen isotope composition. Trends in Plant Science 6:121-126

Ewel J.J., Madriz A., Tosi J.A. 1976. Zonas de vida de Venezuela. Memoria explicativa sobre el mapa ecológico. Ministerio de Agricultura y Cria, Caracas.

Farquhar G.D. and Sharkey T.D. 1982. Stomatal conductance and photosynthesis. Annual Review of Plant Physiology 33:317-345.

Genty B., Briantais J.-M. and Baker N.R. 1989. The relationships between the quantum yield of photosynthetic electron transport and quenching of chlorophyll fluorescence. Biochimica et Biophysica Acta 990:87-92.

Girón C., Tortolero J. and Sánchez P. 2007. Theobroma cacao L. (Sterculiaceae) en la región nororiental de la Isla Margarita, Estado Nueva Esparta, Venezuela. Plant Genetic Resources Newsletter FAO/IPGRI 138:1-4.

González-Jiménez E. 1999. El cacao en Venezuela. Papeles de Fundacite Aragua. <http://www.fundacitearagua.gob.ve/pdf/pf20040507-01cacao_egj.pdf>. Consulted: 30 ${ }^{\text {th }}$ June 2015.

Hoyos J.F. 1985. Flora de la Isla de Margarita. Monografía No. 34, Sociedad y Fundación la Salle de Ciencias Naturales, Caracas.

ICCO [The International Cocoa Organization] 2015. Quarterly Bulletin of Cocoa Statistics, Vol. XXXIX, No. 2, Cocoa year 2014/15. <http://www.icco.org/statistics/production-and-grindings/production.html> Consulted: $28^{\text {th }}$ march 2016.

Isaac M.E, Thimmer V.R. and Quashie-Sam S.J. 2007. Shade tree effect in a 8 years old cocoa agroforestry system: biomass and nutrient diagnosis of Theobroma cacao by vector analysis. Nutrient Cycling in Agroecosystems 78:155-165.

Jaimez R.E., Tezara W., Coronel I. and Urich R. 2008. Ecofisiología del cacao (Theobroma cacao): su manejo en el sistema agroforestal. Sugerencias para su mejoramiento en Venezuela. Revista Forestal Venezolana 52:253-258.

Jaimez R.E., Araque O., Guzman D., Mora A., Espinoza W. and Tezara W. 2013. Agroforestry systems of timber species and cacao: survival and growth during the early stages. Journal of Agriculture and Rural Development in the Tropics and Subtropics 114:1-11.

Joly R.J and Hahn D.T. 1989. Net assimilation of cacao seedlings during periods of plant water deficit. Photosynthesis research 21:151-159.

Marcano-de Segovia M.J. 2007. Cartografía genética de factores del rendimiento y de caracteres morfológicos en una población cultivada de cacao Criollo "moderno" (Theobroma cacao L.) mediante un análisis de asociación. PhD Thesis, Universidad de Los Andes. http://bdigital.ula.ve/index.php/princi$\mathrm{pal} / \mathrm{archivosdoc} / 489$.

Moser G., Leuschner C., Hertel D., Hölscher D., Köhler M., Leitner D., Michalzik B., Prihastanti E., Tjitrosemito S. and Schwendenmann L. 2010. Response of cacao trees (Theobroma cacao) to a 13 month desiccation period in Sulawesi, Indonesia. Agroforestry Systems 79: 171-187.

Motamayor J.C., Lachenaud P., da Silva e Mota J.W., Loor R., Kuhn D.N. Brown J.S. and Schnell R.J. 2008. Geographic and genetic population differentiation of the Amazonian chocolate tree (Theobroma cacao L.). PLoS ONE 3:e3311.

Motamayor J.C., Risterucci A.M., Lopez P.A., Ortiz C.F., Moreno A. and Lanaud C. 2002. Cacao domestication I: the origin d the cacao cultivated by the Mayas. Heredity 89:380-386.

Niinemets Ũ. and Kull O. 1998. Stoichiometry of foliar carbon constituents varies along light gradients in temperate woody canopies: implication for foliage morphological plasticity. Tree Physiology 18:467-479.

Pereyra G. 2007. Eficiencia de uso de agua en diferentes cultivares de germoplasma de cacao (Theobroma cacao L.) en Venezuela. BSc Thesis, Universidad Central de Venezuela, Venezuela. 64 pp.

Rada F., Jaimez R.E., García-Nuñez C., Azócar A. and Ramírez M.E. 2005. Relaciones hídricas e intercambio de gases en Theobroma cacao var. Guasare bajo períodos de déficit hídrico. Revista de la Facultad de Agronomía (LUZ) 22:112-120.

Tezara W., Coronel I., Urich R., Marín O., Jaimez R. and Chacón, I. 2009. Ecophysiological plasticity of cocoa trees (Theobroma cacao L.) from different environments of Venezuela. III Congreso Latino Americano de Ecología and IX Congreso de Ecología do Brasil. Săo Lourenço, MG pp: 1-5. Available in: < http://www.seb-ecologia.org.br/2009/resumos_professores/wilmer_tezara.pdf > 
Received:

March 10th, 2015

Accepted:

June 25th, 2015
Tezara W., Fernández M.D., Donoso C. and Herrera A. 1998. Seasonal changes in photosynthesis and stomatal conductance in five plant species from a semiarid ecosystem. Photosynthetica 35:399-410.

Tscharntke T., Clough Y., Bhagwat S.A., Buchori D., Faust H., Hertel D., Hölscher D., Juhrbandt J., Kessler M., Perfecto I., Scherber C., Schroth G., Veldkamp E. and Wanger T.C. 2011. Multifunctional shade-tree management in tropical agroforestry landscapes - a review. Journal of Applied Ecology 48:619-629. 